\title{
Commentary to "How international are the top ten international journals of criminology and criminal justice?" by Hary Hugo Fruhling
}

\author{
Hary Hugo Frühling ${ }^{1}$ \\ Published online: 3 December 2019 \\ (C) Springer Nature B.V. 2019
}

The article "How international are the top ten international journals of criminology and criminal justice?" makes a significant contribution to the analysis of the production and dissemination of contemporary knowledge as well as the flow of ideas incorporated into public policy and debate in different countries. The authors show that high-impact ${ }^{1}$ journals on criminology or criminal law that call themselves international are, in fact, not very international.

The academics on their editorial boards, the authors of their articles, and the origin of the data they discuss come predominately from the USA and the UK. What's more, they do not display interest in collaborating with academics from other regions of the world. A good portion of collaborative articles include only academics from the so-called Anglosphere. Moreover, these academics belong to a relatively limited number of universities.

This study is based on a selection of criminology and criminal law journals that call themselves international and are high-impact according to the SCImago Journal Ranking (SJR) on Law, which ranks each journal's impact based on the number of times their articles are cited. The selected journals have high SJR indicators, which indicates scientific influence based on citations of the articles. This ranking reflects influence on the academic community, but not on those who apply the knowledge practically. As such, it is certainly not the only way to measure the impact of an academic publication; however, it is the most widely used method.

As a result of the hegemony of English in academic production and exchange, most cited articles have been written in English and are published in English-language journals. In practice, the SCImago Ranking absolutely marginalizes law journals from Germany, France, Italy, and Spain despite the influential criminal legal traditions and vigorous intellectual communities in these countries.

\footnotetext{
${ }^{1}$ Impact is measured in the number of weighted citations received by the documents published in the selected journal in the selected year from the three previous years.
}

Hary Hugo Frühling

hfruhlin@iap.uchile.cl 
One consequence gleaned from the study in question is related to the content being analyzed: Scientific academia with the highest impact bypasses issues that could be of great interest outside the hegemonic countries. It overlooks theoretical frameworks that may not be the most widely used as well as the enriched analysis that comes with data sources more diverse than those processed by academics in the USA or the UK. In that sense, ideas only flow in one direction: from countries in the north to those in the south.

On the other hand, and as the authors also astutely note, due to the cultural nature and the importance of legal practice in each country, legal production tends to be essentially national. That is why none of the journals selected for this study were on criminal law. The law journals with the greatest impact according to the SCImago Ranking are from the USA or England, but they are not criminal law journals. These journals very probably have little influence on legal practice in countries other than the USA or the UK.

The most productive academics in the field of criminology or criminal law-those who write in the scientific journals selected by the authors - are part of an academic community that is restricted in terms of national origin and language. Of course, this is not due to deliberate ethnocentrism or disdain for what happens in Continental Europe, Latin America, or Asia. Rather, it is a reflection of their belonging to an academic, intellectual, and institutional community rooted in the USA and the UK, which is where their readers and those they wish to influence and whose opinion they value are. They measure impact and recognition in the top universities on academic reputation rankings.

It is paradoxical and certainly draws attention that the researchers on the editorial boards of journals that call themselves international write and collaborate predominantly with academics from their own countries. While this reflects the richness and diversity of the academic world in the USA and the UK in Europe, it also reveals a limited vision of internationalization of academia.

Two conclusions seem to emerge: First, there is distance between academic reflection on criminal justice with comparative or international pretensions and legal practice around the world. As noted, all the journals selected by the authors are social science or interdisciplinary journals. While they may focus on the criminal justice system, they are not specifically law journals.

Second, the reality of the academic space tends to be extremely hierarchical and selfcontained. As a result, a strong core network of collaboration forms among prestigious universities, scientific journals, and collaborative research projects, relegating those outside that network to the periphery.

Where do the academics on this periphery publish? Probably in lesser impact or national journals. Others address issues like violence, gangs, and police reform from an interdisciplinary perspective in a journal dedicated to their geographic and cultural area. In Latin America, these topics are notoriously addressed from perspectives of sociology, political science, or urban studies in journals like Latin American Politics and Society (Mazzaro 2018; Ahnen 2007; Krause 2014) and Latin American Research Review (Freire 2018; Bruneau 2014).

As the authors note, genuine progress toward internationalization of academic production on criminology and criminal law would require several players to acknowledge that the phenomenon exists. Of course, universities on the so-called periphery of academic production must pay special attention to the quality of criminology training. However, authors and members of editorial and academic boards from the highest impact journals must also recognize that the discipline and production of knowledge would benefit from a broader perspective than what they currently recognize as international research. 


\section{References}

Ahnen, R. (2007). The politics of police violence in democratic Brazil. Latin American Politics and Society, 49(1), 141-164. https://doi.org/10.1111/j.1548-2456.2007.tb00377.x.

Bruneau, T. C. (2014). Pandillas and security in Central America. Latin American Research Review, 49(2), 152172. Project MUSE. https://doi.org/10.1353/lar.2014.0022.

Freire, D. (2018). Evaluating the effect of homicide prevention strategies in São Paulo, Brazil: a synthetic control approach. Latin American Research Review, 53(2), 231-249. https://doi.org/10.25222/larr.334.

Krause, K. (2014). Supporting the iron fist: crime news, public opinion, and authoritarian crime control in Guatemala. Latin American Politics and Society, 56(1), 98-119. https://doi.org/10.1111/j.15482456.2014.00224.x.

Mazzaro, K. (2018). Crime and the construction of political order in Latin America. Latin American Politics and Society, 60(4), 113-122. https://doi.org/10.1017/lap.2018.43.

Publisher's Note Springer Nature remains neutral with regard to jurisdictional claims in published maps and institutional affiliations. 